\title{
ANALYSIS BIOMECHANICS POINTING DAN SHOOTING PETANQUE PADA ATLET TC PON XX PAPUA
}

\author{
Oleh, \\ Friska Sari Gracia Sinaga ${ }^{1}$, Ibrahim ${ }^{1}$ \\ ${ }^{1}$ Program Studi Ilmu Keolahragaan, Universitas Cenderawasih \\ Email: sarifriska.sinaga28@gmail.com
}

\begin{abstract}
Abstrak
PON XX tahun 2020 sudah di depan mata. Seluruh komponen baik penyelenggara sampai kepada cabang-cabang olahraga harus mempersiapkan diri menuju kegiatan keolahragaan terbesar di Indonesia. Meskipun olahraga petanque merupakan olahraga baru di Indonesia, namun hampir di seluruh wilayah di Indonesia memiliki kontingen untuk olahraga ini. Petanque adalah suatu bentuk permainan yang tujuannya melempar bola besi sedekat mungkin dengan bola kayu dan kaki harus berada di lingkaran kecil. Dilihat dari tujuan mekanika utama dari cabang olahraga petanque dari kajian biomekanika olahraga adalah "mencapai ketepatan maksimal". Artinya adalah bagaimana atlet dapat menempatkan bola sesuai dengan sasaran yang telah ditetapkan, dengan cara melempar baik itu dengan tehnik pointing maupun shooting. Analisis gerak secara biomekanika dapat dilakukan dengan beberapa cara. Salah satunya dengan menggunakan teknologi kinovea. Teknologi kinovea adalah teknologi yang dapat mengkombinasikan kamera dengan computer yang bisa menganalisis sudut, kecepatan, dan ketinggian bola lemparan baik pointing maupun shooting pada olahraga petanque. Pelaksanaan Penelitian ini dilaksanakan pada bulan Juni tahun 2019, diikuti 18 peserta penelitian. Adapun metode yang digunakan dalam penelitian ini yakni menggunakan metode kuantitatif dengan pendekatan deskriptif. Hasil penelitian ini menunjukkan adanya standarisasi gerakan pada gerakan pointing dan shooting. Standar ini dapat digunakan sebagai bahan evaluasi gerakan khususnya pada atlet FOPI Papua menuju PON XX di Papua. Selain itu juga, pelatih dapat meanalisis, merancang dan mengevaluasi gerakan atlet sehingga dapat mencapai gerakan maksimal sesuai dengan standar gerakan yang merupakan hasil dari penelitian ini.
\end{abstract}

Kata kunci: Analysis Biomechanics, Pointing, Shooting.

\section{A. PENDAHULUAN}

PON XX tahun 2020 sudah di depan mata. Seluruh komponen baik penyelenggara sampai kepada cabang-cabang olahraga harus mempersiapkan diri menuju kegiatan keolahragaan terbesar di Indonesia. Persiapan demi persiapanpun telah dilakukan menuju keberhasilan PON XX tahun 2020 yang diselenggarakan di Papua. Dari seluruh wilayah di Indonesia akan memberikan kontribusi pada masing-masing cabang olahraga. Demikian pula, cabang olahraga Petanque yang pada musim ini masuk dalam daftar cabang olahraga yang dipertandingkan. 
Petanque merupakan salah satu olahraga yang akan dipertandingan di ajang bergengsi se Indonesia, yaitu Pekan Olahraga Nasional ke XX yang diselenggarakan di Papua. Hal ini tentunya menjadi perhatian khusus bagi bidang keolahragaan yang ada di Papua. Dalam rangka mencapai tujuan prestasi yang di impikan, pihak-pihak yang terkait tentunya harus berbenah diri. Pada dasarnya olahraga petanque merupakan olahraga yang mudah untuk dilakukan karena tidak membutuhkan lapangan yang luas, alat olahraga yang mudah didapat dan tentunya harganya terjangkau. Namun demikian, untuk teknis permainan petanque sendiri memiliki tingkat konsentrasi yang tinggi, ketepatan dan skill yang tinggi. Oleh karena itu, tentunya harus melihat dan menganalisis bagaimana gerakan-gerakan dala permainan petanque ditinjau dari gerak biomekanikanya. Petanque memiiki 2 teknik permainan yaitu pointing dan shooting. Sebelum lebih lanjut mengenai cabang olahraga ini, maka di bawah ini akan dijabarkan bagaimana sejarah olahraga ini, bagaimana cara bermain, dan perlengkapan apa saja yang dibutuhkan pada cabang olahraga petanque ini.

Olahraga petanque sesungguhnya merupakan olahraga permainan yang sangat sederhana dan bisa dilakukan oleh siapa saja tanpa membatasi kelompok usia dan tidak membutuhkan sarana dan prasana yang luas. Petanque bisa diaminkan dilapangan apa saja, hanya membutuhkan 6 x/12 meter luasnya dan membutuhkan bola besi (bosi) dan bola kayu (boka). Perkembangan petanque di Papua juga sangat pesat. Hal ini jelas terlihat ketika dilakukan open tournament petanque di Fakultas Ilmu Keolahragaan UNCEN, ada banyak yang ikut serta dalam kegiatan tersebut.

Menurut Confederation Mondiale Sport Boules (2015), Petanque adalah bentuk permainan boules yang tujuannya melempar bola besi (boules) sedekat mungkin dengan bola kayu yang disebut jack dan kedua kaki harus berada di lingkaran kecil dengan ukuran diameter minimal 7,05 cm dan maksimal 8,00 cm dan berat antara 650 gram dan 800 gram yang dihantarkan. Untuk pemain dibawah 11 tahun dapat menggunakan bosi dengan berat 600 gram dan diameter $65 \mathrm{~mm}$ asalkan bola besi tersebut dibuat oleh produsen resmi. Boka adalah bola berukuran diameter $0,3 \mathrm{~cm}$ dan berat harus diantara 10 - 18 gram yang terbuat dari kayu dan tidak dapat diangkat oleh magnet. Selain dari kayu ada bahan lain seperti plastik.

Ada beberapa nomer yang dipertandingkan pada cabang olahraga petanque seperti: triple putra putri, double putra putri, single putra putri, dan shooting. Dalam 
permaian petanque, terdapat 2 hal yang perlu diperhatikan yaitu shooting dan pointing. Pointing merupakan cara melempar atau menghantarkan bola besi yang alami. Teknik ini banyak digunakan tidak hanya pada satu karakter lapangan saja melainkan beberapa jenis karakter lapangan. Oleh sebab itu teknik ini lebih banyak digunakan oleh atlet pada saat bermain olahraga petanque.( Smith, 1999: 5). Sedangkan untuk shooting, adalah salah satu tehnik dalam permainan petanque yang memerlukan akurasi, konsentrasi yang tinggi dan ketepatan dalam melakukan shooting.

Untuk nomor pertandingan shooting dilakukan pada jarak enam meter, tujuh meter, delapan meter, dan sembilan meter dengan point yang bisa didapat 0 point, 1 point, 3 point, dan 5 point tiap shooting yang berhasil. Penembak hanya diberi kesempatan satu kali shooting tiap jarak disiplin yang diberikan. Menurut Hermawan (2012:17), berdasarkan tujuan mekanika utamanya dari permainan petanque termasuk ke dalam cabang olahraga yang mempunyai tujuan mencapai keseimbangan dan ketepatan maksimal. Artinya lemparan yang dilakukan harus tepat mengenai sasaran tertentu untuk mendapatkan point kemenangannya.

Dilihat dari tujuan mekanika utama dari cabang olahraga petanque dari kajian biomekanika olahraga adalah "mencapai ketepatan maksimal". Artinya adalah bagaimana atlet dapat menempatkan bola sesuai dengan sasaran yang telah ditetapkan, dengan cara melempar baik itu dengan tehnik pointing maupun shooting.

Analisis gerak secara biomekanika dapat dilakukan dengan beberapa cara. Salah satunya dengan menggunakan teknologi kinovea. Teknologi kinovea adalah teknologi yang dapat mengkombinasikan kamera dengan computer yang bisa menganalisis sudut, kecepatan, dan ketinggian bola lemparan baik pointing maupun shooting pada olahraga petanque. Kinovea terdapat lebih banyak menu pilihan yang mudah dan tidak terlalu rumit untuk digunakan pada analisis gerakan khususnya gerakan pointing dan shooting pada olahraga petanque. Kinovea dapat mengubah kecepatan video dengan slow motion sehingga gerak video lebih lambat dan memudahkan dalam menganalisis.

Dengan mengkombinasikan teknologi dengan olahraga petanque diharapkan mampu untuk mengumpulkan data dari atlet seperti bagaimana gerakan ponting dan shooting. Menurut Souef (2015: 39) gerakan-gerakan awalan pada permainan petanque sangat mempengaruhi hasil pointing dan shooting permainan petanque. Dengan demikian, analisis yang dimaksud adalah bertujuan untuk mengetahui kesalahan dalam 
gerakan dan gerak bola akan menciptakan gerakan yang ideal, mengetahui kesalahan dalam melakukan teknik dengan lengkap dan akurat, dan menciptakan atlet yang berpotensi untuk menjadi juara khususnya pada pertandingan PON XX yang akan dilaksanakan pada tahun 2020 di Papua.

\section{B. METODOLOGI PENELITIAN}

Untuk mencapai tujuan dalam penelitian ini, maka pada penelitian ini menggunakan metode penelitian kuantitatif dengan pendekatan deskriptif. Metode penelitian kuantitatif dapat dikatakan sebagai metode penelitian yang berlandaskan pada filsafat positivisme.( Sugiyono, 2008: 8). Sedangkan menurut Maksum (2012: 68) penelitian deskriptif yaitu penelitian yang digunakan untuk menggambarkan fenomena tertentu. Penelitian ini menggunakan software kinovea yaitu perangkat lunak analisis gerak yang diharapkan mampu menganalisis gerakan pada saat atlit melakukan pointing dan shooting sehingga dapat meningkatkan pemahaman tentang keterampilan motorik analisis dengan penerapan sains pada cabang olahraga petanque. Software kinovea yang digunakan adalah versi 0.8.26.

Teknik analisis data dalam penelitian ini menggunakan analisis deskripsi, yaitu menganalisis video menggunakan software kinovea yang bertujuan untuk melihat bagaimana gerakan-gerakan pointing dan shooting yang dilakukan oleh atlet petanque Papua. Ada 3 fase yang akan dianalisis yaitu fase back swing, swing, and releas dimana masing-masing fase akan dianalisis berdasarkan gerakan dalam video dan disimpulkan berdasarkan teori-teori yang telah dikembangkan oleh ahlinya.

Apabila penelitian yang diusulkan ini terlaksana maka kegunaan hasil penelitian akan dapat dijadikan pegangan oleh pelatih dalam menyusun program latihannya, terutama dalam teknik permainan pointing dan shooting. Selain itu, hasil penelitian tersebut akan dijadikan sebagai informasi dalam melakukan studi berikutnya, yaitu yang diarahkan untuk mengembangkan jenis-jenis latihan yang sesuai untuk meningkatkan teknik pointing dan shooting atlet petanque khususnya atlit petanque papua. Dasar modal ilmiah yang diperoleh dari penelitian tersebut akan menjadi modal yang sangat berharga dalam penelitian-penelitian berikutnya, khususnya pada pengembangan program-program latihan yang dilakukan oleh Pelatih dan pengurus FOPI di daerah maupun tingkat nasional. 


\section{HASIL DAN PEMBAHASAN PENELITIAN}

1. Hasil Penelitian

Pada dasarnya, hal-hal yang akan dilakukan dalam penelitian ini merupakan analisis gerakan biomkenik. Analisis gerakan pointing dan shooting dilakukan dengan menggunakan teknologi kinovea. Teknologi kinovea mengkombinasikan data kamera dengan komputer yang bisa menganalisis sudut, kecepatan, dan ketinggian bola lemparan pointing dan shooting olahraga petanque. Kinovea terdapat lebih banyak menu pilihan yang mudah dan tidak terlalu rumit untuk digunakan menganalisis gerakan. Kinovea dapat mengubah kecepatan video dengan slow motion sehingga gerak video lebih lambat dan memudahkan dalam menganalisis.

Dengan mengkombinasikan teknologi dengan olahraga petanque diharapkan mampu untuk mengumpulkan data dari atlet seperti bagaimana gerakan back swing, swing, release pada pointing dan shooting cabang olahraga petanque. Menurut Souef (2015: 39) Back swing olahraga petanque merupakan gerakan awalan ketika akan melakukan pointing atau shooting yaitu menggerakkan lengan kearah belakang melewati sumbu tubuh. Release saat pointing atau shooting adalah saat dimana bola lepas dari tangan, ketika bola release pada waktu yang tepat akan berpengaruh terhadap ketinggian dan laju bola. Mengetahui kesalahan dalam gerakan dan gerak bola akan menciptakan gerakan yang ideal, mengetahui kesalahan dalam melakukan teknik dengan lengkap dan akurat, dan menciptakan atlet yang berpotensi untuk menjadi juara khusunya pada pertandingan PON XX di Papua. Adapun hasil analisis gerakan shooting dan pointing akan dijabarkan dibawah sesuai dengan tujuan penelitian ini.

a. Hasil Analisis Gerakan Shooting

Dalam penelitian ini ada empat indikator utama yang menentukan shooting, yaitu sudut backswing, swing, sudut release, dan tinggi bola. Keempat indikator tersebut saling terkait dan saling mempengaruhi. sudut backswing akan mempengaruhi kecepatan swing, dan kecepatan swing akan mempengaruhi sudut release bola, dan tiga indikator tersebut akan menghasilkan tinggi maksimal bola. Dalam shooting tidak terdapat acuan yang pasti tentang keempat indikator tersebut. Berdasarkan hasil penelitian menghasilkan shooting yang paling baik dengan sudut backswing, sudut release, kecepatan swing dan tinggi maksimal bola, pada jarak 7 meter yang dilakukan oleh 4 atlet TC PON Petanque Papua yang efektif. 
Shooting yang baik dilakukan pada atlet pertama pada kesempatan kedua dan ketiga, pada atlet kedua kesempatan kedua dan ketiga, pada atlet ketiga kesempatan ketiga dan atlet yang keempat kesempatan yang kedua, dengan data sebagai berikut:

Tabel 1

Data Shooting Atlet TC PON Petanque Papua

\begin{tabular}{cllcccc}
\hline No & Atlet & Lemparan & BS & S & R & TB \\
\hline 1 & Pertama & Kedua & 79 & $3.91 \mathrm{~m}$ 's & 83 & $1.63 \mathrm{~m}$ \\
\hline 2 & Pertama & Ketiga & 80 & $3.82 \mathrm{~m}$ 's & 81 & $1.45 \mathrm{~m}$ \\
\hline 3 & Kedua & Kedua & 78 & $3.82 \mathrm{~m}$ 's & 83 & $1.52 \mathrm{~m}$ \\
\hline 4 & Kedua & Ketiga & 79 & $3.50 \mathrm{~m}$ 's & 80 & $1.52 \mathrm{~m}$ \\
\hline 5 & Ketiga & Ketiga & 79 & $3.78 \mathrm{~m}$ 's & 81 & $1.60 \mathrm{~m}$ \\
\hline 6 & Keempat & Kedua & 80 & $3.63 \mathrm{~m}$ 's & 81 & $1.58 \mathrm{~m}$ \\
\hline
\end{tabular}

Data diatas adalah data shooting yang dilakukan oleh keempat atlet TC PON Petanque Papua. Dengan hasil sudut backswing 78 o- 80 o sudut ini adalah yang efektif dilakukan karena memberi peluang ruang gerak yang ideal dalam melakukan shooting jarak 7 meter. Ruang gerak yang dimaksudkan dalam hal ini adalah pengaturan kecepatan gerak yang dihasilkan, pengaturan/kecepatan gerak/memberikan pengaruh pada penguasaan teknik dan laju bola yang dihasilkan. Sudut release $80 \mathrm{o}-83$ o yang paling efektif dilakukan karena memberi pengaruh terhadap lepasan yang tepat saat melakukan lepasan bola sehingga bola bisa mengenai sasaran pada jarak 7 meter. Dengan rata- rata kecepatan swing $3.66 \mathrm{~m} / \mathrm{s}$ yang dilakukan karena berpengaruh terhadap laju bola yang dihasilkan untuk menempuh jarak 7 meter dan dengan massa bola 680-700 gram. dari tiga indikator diatas maka dibutuhkan tinggi maksimal 1,45 1,63 meter untuk menghasilkan bola yang langsung mengarah kearah taget tanpa harus menyentuh medan lain terlebih dahulu. Sehingga dapat menghasilkan shooting yang baik dengan bola berhenti langsung atau tidak jauh bergerak dari titik awal bola sasaran berada.

\section{b. Hasil Analisis Gerakan Pointing}

Selanjutnya, hasil dari gerakan Pointing adalah terdapat empat faktor yang mempengaruhi ketepatan pointing pada jarak 7 meter olahraga petanque, empat faktor tersebut adalah back swing, swing, release, dan tinggi bola maksimal dimana empat faktor tersebut saling mempengaruhi satu sama lain sekalipun tidak menutup kemungkinan ada faktor lain yang dapat mempengaruhi. Dari penelitian ini didapatkan hasilnya adalah sebagai berikut: 
Tabel 2

Hasil Pointing Atlet Pertama

\begin{tabular}{cccccc}
\hline No & $\mathrm{BS}\left({ }^{\mathrm{O}}\right)$ & $\mathrm{R}\left({ }^{\mathrm{O}}\right)$ & $\mathrm{S}(\mathrm{m} / \mathrm{s})$ & $\mathrm{TB}(\mathrm{m})$ & Poin \\
\hline 1 & 58 & 90.2 & 3.70 & 1.63 & 0 \\
\hline 2 & 50 & 87 & 1.20 & 1.52 & 8 \\
\hline 3 & 54 & 89 & 3.34 & 1.35 & 0 \\
\hline 4 & 51 & 102 & 0.51 & 2.13 & 6 \\
\hline 5 & 55 & 89 & 0.87 & 1.66 & 4 \\
\hline 6 & 56 & 89 & 3.84 & 1.44 & 0 \\
\hline 7 & 55 & 85 & 3.88 & 1.75 & 0 \\
\hline 8 & 49 & 86 & 1.20 & 1.57 & 4 \\
\hline 9 & 58 & 86 & 3.83 & 1.70 & 0 \\
\hline 10 & 54 & 81 & 0.74 & 1.51 & 2 \\
\hline
\end{tabular}

Tabel 3

Hasil Pointing Atlet Kedua

\begin{tabular}{ccc|c|cc|}
\hline No & $\mathrm{BS}\left({ }^{\circ}\right)$ & $\mathrm{R}\left({ }^{\mathrm{O}}\right)$ & $\mathrm{S}(\mathrm{m} / \mathrm{s})$ & $\mathrm{TB}(\mathrm{m})$ & Poin \\
\hline 1 & 64 & 71 & 1.32 & 1.56 & 2 \\
\hline 2 & 63 & 84 & 0.40 & 1.34 & 9 \\
\hline 3 & 66 & 83 & 4.16 & 1.39 & 0 \\
\hline 4 & 62 & 75 & 1.05 & 1.29 & 3 \\
\hline 5 & 69 & 84 & 1.08 & 1.30 & 1 \\
\hline 6 & 65 & 75 & 3.56 & 1.20 & 0 \\
\hline 7 & 70 & 81 & 4.28 & 1.37 & 0 \\
\hline 8 & 65 & 83 & 4.81 & 1.40 & 0 \\
\hline 9 & 66 & 90 & 0.99 & 1.45 & 8 \\
\hline 10 & 68 & 74 & 5.04 & 1.29 & 4 \\
\hline
\end{tabular}

Tabel 4

Hasil Pointing Atlet Ketiga

\begin{tabular}{cccccc}
\hline No & BS $\left({ }^{\mathrm{O}}\right)$ & $\mathrm{R}\left({ }^{\mathrm{O}}\right)$ & $\mathrm{S}(\mathrm{m} / \mathrm{s})$ & $\mathrm{TB}(\mathrm{m})$ & Poin \\
\hline 1 & 79 & 80 & 3.40 & 1.73 & 0 \\
\hline 2 & 80 & 72 & 3.74 & 1.16 & 0 \\
\hline 3 & 78 & 74 & 0.82 & 1.51 & 5 \\
\hline 4 & 79 & 79 & 0.78 & 1.52 & 4 \\
\hline 5 & 72 & 76 & 1.25 & 1.58 & 2 \\
\hline 6 & 75 & 81 & 3.69 & 2.36 & 0 \\
\hline 7 & 80 & 76 & 1.00 & 1.58 & 4 \\
\hline 8 & 86 & 72 & 1.48 & 1.61 & 4 \\
\hline 9 & 87 & 74 & 4.31 & 1.65 & 0 \\
\hline 10 & 84 & 75 & 3.09 & 1.41 & 0 \\
\hline
\end{tabular}

Tabel 5

Hasil Pointing Atlet Keempat

\begin{tabular}{cccccc}
\hline No & $\mathrm{BS}\left({ }^{\mathrm{O}}\right)$ & $\mathrm{R}\left({ }^{\mathrm{O}}\right)$ & $\mathrm{S}(\mathrm{m} / \mathrm{s})$ & $\mathrm{TB}(\mathrm{m})$ & Poin \\
\hline 1 & 58 & 88 & 0.41 & 1.85 & 1 \\
\hline 2 & 44 & 99 & 0.83 & 1.30 & 7 \\
\hline 3 & 59 & 83 & 2.75 & 1.75 & 4 \\
\hline 4 & 48 & 85 & 0.37 & 1.64 & 8 \\
\hline 5 & 60 & 89 & 5.53 & 1.60 & 0 \\
\hline
\end{tabular}




\begin{tabular}{ccccccc}
6 & 60 & 83 & 6.15 & 1.77 & 0 \\
\hline 7 & 60 & 88 & 1.97 & 1.66 & 1 \\
\hline 8 & 58 & 88 & 0.41 & 0.20 & 1 \\
\hline 9 & 59 & 83 & 2.75 & 1.75 & 4 \\
\hline 10 & 57 & 86 & 5.77 & 1.48 & 0 \\
\hline
\end{tabular}

Data tersebut adalah data hasil analisis pointing pada jarak 7 meter. Dari data tersebut dijelaskan bahwa Sudut lengan saat back swing yaitu antara $48^{\circ}-69^{\circ}$ seperti yang dilakukan oleh subjek Pertama dan Kedua yang memberikan ruang gerak yang ideal untuk mengatur kecepatan ayunan sehingga dalam melakukan lepasan bola akan lebih mudah mengatur waktu yang pas. Sehingga dengan begitu dapat mencapai ketepatan dan hasil yang maksimal yaitu poin 10 . Sudut di atas $69^{\circ}$ atau dibawah $48^{\circ}$ merupakan sudut yang kurang ideal karena jika sudut back swing terlalu besar maka sudut elevasi yang akan dibentuk akan semakin besar pula. Jika momentum terlalu besar kecepatan semakin besar pula sehingga akan melebihi dari target atau sasaran. Hal tersebut sesuai dengan teori momentum yaitu hasil kali massa benda dengan kecepatan benda. Semakin besar massa dan juga kecepatan benda maka benda tersebut memiliki momentum yang besar pula.

\section{Pembahasan Penelitian}

Olahraga Petanque yang terbilang baru di Indonesia ternyata memiliki hiporia yang cukup besar. Hal ini terlihat jelas karena diberbagai daerah sudah ada pengurus cabang Olahraga ini. Bahkan sampai pada wilayah Indonesia Timur, khususnya di Papua. Olahraga yang memiliki 2 jenis tehnik dasar ini dianggap sebagai Olahraga sederhana yang biasa dilakukan siapa saja. Dari hasil penelitian yang dilakukan, bahwa dengan hasil sudut backswing 78 o- 80 o sudut ini adalah yang efektif dilakukan karena memberi peluang ruang gerak yang ideal dalam melakukan shooting jarak 7 meter. Sedangkan sudut releasenya yang paling efektif dilakukan ialah Sudut release 80o- 83 o yang memberi pengaruh terhadap lepasan bola mengenai sasaran di jarak 7 meter. Disisi lain, untuk hasil gerakan pointing yang terdapat empat factor yang mempengaruhi ketepatan gerakannya. Yang pertama yaitu kecepatan ayunan yang ideal yaitu 0,33 $0,87 \mathrm{~m} / \mathrm{s}$, nilai dibawah ataupun di atas dari angka diatas mengakibatkan hasil yang tidak ideal. Untuk sudut release yang ideal adalah antara $66^{\circ}-94^{\circ}$. Apabila sudut release terlalu cepat maka bola tidak mencapai tinggi maksimal. Sedangkan jika sudut release terlalu kecil maka sudut elevasi yang terbentuk akan kecil pula. 


\section{Dampak Kegiatan}

Sebagai Olahraga baru yang belum dikaji oleh banyak pihak, maka dampak dari penelitian ini jelas sangat besar. Informasi yang diperoleh yang terkait pada standar gerakan yang dilakukan pada saat ponting maupun shooting dapar diketahui sehingga atlet yang pada kesempatan ini dapat lebih mudah mengevaluasi gerakan masingmasing. Dengan adanya informasi ini juga memberikan pengetahuan bagi pelatih sehingga dapat memberi latihan-latihan yang disesuaikan dengan hasil gerakan yang ada pada penelitian ini. Jika pada perjalanannya, seluruh gerakan sudah dilaksanakan dengan baik maka besar kemungkinan prestasi Olahraga khususnya pada cabang Olahraga petanque ini dapat dicapai pada saat pelaksanaan PON XX di Papua.

\section{KESIMPULAN}

Simpulan dari hasil penelitian yang telah dipaparkan di pembahasan, maka pada penelitian ini dapat disimpulkan bahwa terdapat 4 indikator utama yang sangat berpengaruh pada hasil shooting olahraga petanque, yaitu Backswing, swing, release, dan tinggi bola. Jika salah satu indikator tersebut ada yang dominan maka indikator yang lain juga harus menyesuaikan karena 4 indikator tersebut saling terkait terhadap hasil shooting yang baik. Demikian halnya untuk pointing, dari hasil penelitian pointing disimpulkan bahwa: 1 . sudut back swing $48^{\circ}$ - $69^{\circ}$ merupakan sudut lengan yang ideal untuk melakukan pointing pada jarak 7 meter karena dengan besar sudut tersebut memberikan keleluasaan ruang gerak yang ideal dalam melakukan pointing jarak 7 meter.

\section{Daftar Pustaka}

Agustina, Ayuk T. 2017. Hubungan Antara Tingkat konsentrasi Terhadap Hasil Ketepatan Shooting Olahraga Petanque Pada Peserta Unesa Petanque Club. Jurnal pendidikan olahraga dan kesehatan. Vol. 5. Hal.392

Anoname. 2015. Cara Menggunakan Dartfish Motion Analysis. (Online). file:///D:/net/Dartfish\%20Motion\%20Analysys\%20-\%20Documents.htm

Basir Annas. (2011). Olahraga Petanque, Cara Bermain dan Sejarahnya. Diakses dari http://sibukforever.blogspot.com/2011/11/olahraga-petanque-cara bermaindan.html, tanggal 15 September 2012.

Bogi Triyadi. (2011). Apa Itu Petanque. Diakses dari http://bola.liputan6.com/read/362674/apaitu-petanque, tanggal 15 September 2012.

Cahyo, Dwi, dkk. 2015. Biomekanik Olahraga. Surabaya : Unesa University Press 
Hermawan, Iwan. 2012. Gerak dasar permainan olahraga petanque. Jakarta : Deputi Pemberdayaan olahraga, Kemenpora.

Maksum, Ali. 2007. Statistik Dalam Olahraga. Surabaya : Unesa University Press.

Pengurus Besar Federasi Olahraga Petanque Indonesia. (2012). Program dan Teknik Dasar Bermain Petanque. Jakarta.

Sudjana. 1992. Statistik. Bandung : Tarsito.

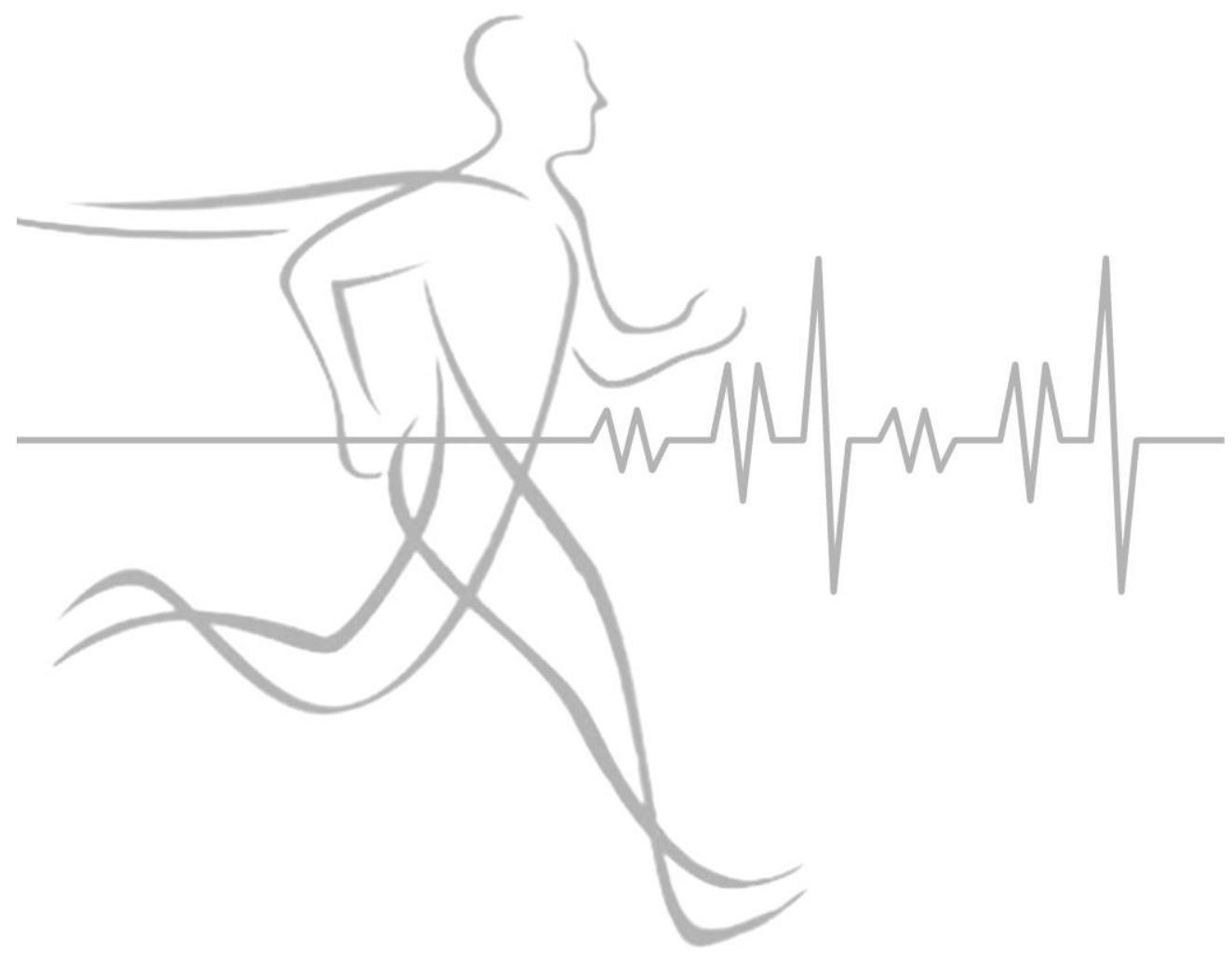

